\title{
EUHTE3E
}

2017, бр. 12, стр. $81-100$.

Professional Paper

UDK 81 Белић A.

doi: $10.5937 /$ sinteze6-14237

811.163.41'373.611

\section{RECEPTION OF BELIC'S LEARNING ON WORD FORMATION IN SLAVIC LANGUAGES}

\author{
Drago V. Tesanovic ${ }^{1}$
}

Abstract: This paper brings into daylight some relevant facts from word formation, which was one of the central disciplines in Serbian language in the past. This, primarily, show Belic's works which, in Slavic world, are accepted as the foundation for this discipline. Therefore, prominent Russian from the end of twentieth century return to the theoretical perspectives of A. Belic, in derivatology, so word formation of his time count as the central discipline. Modeled on Belic's theoretical reviews in derivation, many works by eminent experts in Russian, Czech, and Bulgarian language have appeared. language.

Key words: derivatology, building words, word-formation, reception,

\section{INTRODUCTION}

Derivation researches in Serbian language have long-standing successful starts, but also relatively modest general ranges, especially if compared to the corresponding opportunities in some other Slavic languages. This is showed by extensive chapters about word formation in old grammatical handbooks of our language (Maretić, 1931: 252-358; 1963: 299-420; Belić, 1949: 1-329), as well as in the newer ones (Stevanović, 1975: 387-591; Babić, 1986: 1-550), but also by fairly scarce list of wider, general or specialized researches (Ristić, 1970: 387451; Nikolić, 1967: 1-84), although in the past 20 - 30 years, many smaller contributions about the most different problems of word formation in Serbian (Croatian) language have appeared, (Babić, Matijašević, Ančić-Obradović, Barić, etc.) and from different aspects (most commonly from descriptive, very successfully from confrotative, and sometimes from theoretical). This work will

${ }^{1}$ drago_tesanovic@yahoo.com, University of Banja Luka, Faculty of Philology 
bring some relevant facts from the formation of words in Serbian language based on the model of Professor Aleksandar Belic.

\section{THE IMPORTANCE OF BELIC'S WORKS FOR WORD FORMATION IN SERBIAN LANGUAGE, AS WELL AS IN SLAVIC STUDIES}

We made an ascertainment about derivation works in previous sentences, however, in this article, we want ,to show the importance of scientific creativity of Alexandar Belic, in under the patronage of this discipline. Still, before we start with this discipline, it is necessary to say how professor Belic defines language. Probably, his general definition is known to all, ,Language serves as a mean of communication". However, during the opening of Faculty of Philosophy in Novi Sad, he said: „I will speak about the importance of that science whose subject is the closest to each person, and that is the science of constant companion of all our thoughts and feelings, of its constant expression, its strength and beauty- of our language. Serbian linguists, no matter where they are and what they do, give an important position to Professor Alexander Belic under the patronage of diachronic disciplines, which is completely true. However, if we review Belic's works in details, from word formation area (contemporary Serbian language) it is not difficult to conclude that his works are indispensable, and especially from theoretical aspect. Professor Belic, with his works, laid the foundations to the Slavic derivation, which relevant promienet Slavic linguists show in their works, on Russian, Chech and Bulgarian language. So, Russians place on pedestal Belic's discussion, as the great range of Serbian derivatology about the origin, and for the needs of diminutive and augmentative sufixes in Slavic languages.

To write about Belic's works and represent them in the areas which is, somehow, a long ago neglected, and it seems to us just in that time when it was on a pedestal in Slavic languages and in those whose science represents the core of slavistics. So, Russians place Belic's discussion on pedestal, as the great range of Serbian derivatology of origin and for the needs of diminutive and augmentative suffixes in Slavic languages (Belić, 1901: 134-206). Belic's research is, in fact, in the foundation of modern derivation Slavic science, primarily ,linguistic elaboration of problem of Slavic lingual world differentiation considering word formation data“" (Вендина \& Толстой, 1990: 6), but also considering other significant theoretical contributions. Some of these suffixes, namely, are functionally considered South Slavic, although that group of languages is significantly differentiated, considering many word formation details ( for example, suffix -nic(a) in meaning of location, -ic(a) in motion meaning, suffixes with elements $-c$ and -č in diminutive meaning (Вендина \& Толстой, 1990: 6). In the similar line, there is well known discussion by I. Lekov (1958), and in the last thirty years, derivation researches in Slavic world have experienced extremely strong expansion, especially after extensive discussion on word formation in Czech and Russian languages (Dokulil, 1962; Дмитренко, 1970), but also in some other Slavic languages. All details we talk about 
influenced that derivation over the last few decades, starts markedly to constitute itself as a separate area of linguistic researches, which was limited until now, and from now then, significantly complicated by its connection and intertwining with other, already independent disciplines- like morphology (with morpho-fonology), lexicology and syntax. As for the opportunities in Serbian language, traditional neglect of derivation researches compared to other language areas, as well as, the absence of systematic and continuous work in this areas, must be kept in mind. With this statement we can be assured, if we, for example, check Encyclopedic dictionary of linguistic terms, whose Introduction indicates the areas processed terms are from: among them we find ,phonetics, morphology, syntax, lexicology, lexicography, dialectology (Симеон, 1969: 13-34), and term „derivation“ is not even mentioned (although many guidelines from that terminological system are found in the dictionary, to be understood.

In 1996, the work entitled ,Serbian language at the end of the century"under the patronage of Institute for Serbian language SANU saw the light of the day. In the mentioned work, professor Zivojin Stanojcic says that Formational models of Serbian literary language, of this observed period, show the stability of high degree. In some word classes, for example in noun class, the innovation is, in fact, the matter of custom, usage of certain units of lexical inventory, and not the matter of possible new model, which would only now appear in literary language (Stanojčić, 1996: 123).

\section{THE SUFFIX AS LINGUISTIC MEANS}

Having on mind all these circumstances, it needs to be said that the main directions of derivation researches are clearly indicated and many starting position are considered as refined, and among them we would highlight those that concern the very nature of suffix as a linguistic mean.

Suffix is a linguistic unit which can be considered within a triad: formmeaning-function. As a meaning of suffix, that component of paronym which can be expressed with the assistance of suffix (,zen-a“ and ,zen-ic-a“). Regarding the suffix function, it need to be said that it can be diverse, but two the most general ones can be marked off: a) structural - which brings down itself to grammatical, but also to morphological and derivative function (wherein, in the first case, suffixes shows itself as an affiliation indicator of paronym to certain type of words, while in the second case, it appears as an element with whom a new linguistic unit is formed) and b) semantic-which can be „objectized" (that is, „realistically-semantic") and „subjective“ (that is, ,expressive“). Regarding the first function, it need to be said that it brings down itself to the fact that the suffix is used to mark the meaning after some broadly or narrowly defined characteristic (,person“ - „person by professional affiliation“), while the expressive function brings itself down to expressing the attitude of speech person towards the object of nomination (cur-a - cur-et-ak, cur-et-in-a). 
However, there is less agreement between derivation scientists on the main charachteristics of derivation system of one language as a whole. Here, we will try to present a model of derivation system analysis, that we tried to apply in this work.

Starting from the fact that in the consideration of word formation of one language, on a different hierarchy, different classification criteria can be applied, we chose solving by whom we will derivative-semantically macro field observe as a derivative category, and adequate micro fields as derivative sub-categories. For such a procedure, we find an excuse in the fact that our research does not refer to the unity of word formation system, but only to that one part that refers to denotation of subjects in fiction work by В. Соріс (Тешановић, 2003: 11).

Formative category can be defined as ,the totality of paronyms which, within the formative class, distinguishes itself according to lexical-grammatical features of motivator“, and which can be distinguished from „nouns, adjectives, numbers, pronouns, verbs, adverbs, etc.“ (Молочко, 1984: 146-147). Formative category is similarly defined by some other authors: from formative kind, and it distinguishes itself by not being tided by the unity of formants (Dokulil, 1962: 203-204).

Besides the mentioned classification, we find different classification procedures in literature, in analysis of language word formation. In such a way, for example, Dokulil, as the first, „basic differential feature at forming the formation system stresses the way of forming paronyms, and lexical-grammatical character of paronyms, their affiliation to certain type of word puts on the second position" (Dokulil, 1962: 218). Then, Zenkov in the basis of word formation language system, that is, in the basis of organization of word formation language system, that is, in the basis of paronyms classification, puts ,the unity of lexicalgrammatical feature of motivating words in the juncture, unity with the formation way, mean, procedure" (Зенков, 1969:76). Considering that some paronyms can indirectly be motivated by diverse motivators, that is, motivating words which refer to different types of words, and also the fact that many paronyms can have diverse formative meanings, in many cases, one word (completely or in separate lexical-semantically versions) can refer to different sub-sections of word formation language system (on different formative classes, categories, levels, groups). Based on presented statements, in accordance with the aim of this work, we will be interested in those formative categories which are accomplished by formative means in Serbian language. Formative means are the basis, prefixes, and suffixes.

The structure of formative category, in general, is always binomial. The phenomenon that should be nominated always at the beginning, involves in certain conceptual class, which in a given language has its own categorical expression, and then within that class, it is defined by some feature. The class comes into the formative structure as something that is defined (formative basis), and formant is that element that is used of defining the basis. The formative basis is always simple, while formant can be simple or complex. In Serbian derivation 
literature we find terms „formative basis"and „formative formant", which are to terms " motivating basis"and „formative formant" in Russian language. Formative formant is, both in formal and semantic aspect, the smallest formative element among other elements after which one words is different from the words that are motivationally related to it.

\section{SERBIAN WORD FORMATION - MODEL BY ALEXANDAR BELIC}

After mentioned relevant scientific fact about professor Belic, which are mentioned by his inheritors, and especially foreign scientist for derivation, who claim that word formation lies upon his theoretical fundamentals, it is an honor and pleasure to everyone who reads it, to perceive that Serbian word formation, that is, model by Alexandar Belic is inwrought in contemporary Slavic derivation knowledge.

Yet, Belic defined literature language as that , that fact that it is used for processing literary subjects, it is the representative of cultural opinion", indicating to the need of studying that history of that literary language with the author's language, ,from author to author, from literary kind to literary kind“ (Belić, 1951: $52 ; 36-79)$.

Essentially, the same attitude has got post-Belic's modern linguistics. The most prominent representatives, when determining the need for writing descriptive grammar of contemporary Serbian literary language, are explicit in their demand that „only language of modern authors should justify present grammar standards" (Ivić, 1960).

Listed statements of, both, Serbian and foreign derivation scientists, lead us to accept the analysis of prose works in the language of Branko Copic, from the aspects of word formation. We carried through analysis in the language of Copic within the formative categories nomina agentis and nomina attributiva, where we found some extraordinary results, which are specific in many ways. It is known that in Serbian language, that is, in normative grammars of Serbian language suffixes -ica and -ka are central. In prose works by Copic, suffixes -ica and -ka are also central, within the formative categories as well as within their sub-categories. Our analysis show that suffixes, used for marking subjects, are dominating the language of prominent Serbian author Branko Copic. In this work, we want to draw attention, to all those who want to investigate the language of authors from the aspect of word formations, to have in mind the essential Serbian word formation, for example, Belic's, Boskovic's, Stevanovic's works and works of some other Serbian word formation scientists.

The term nomina agentis is used to summon the names of persons who in motivating words have an agent. The shape of motivating words, thereat, is equal to verb stem which is used for marking former, by which, primarily the namesthe names of doers of actions in complete sense of this word, are carried out. This formative category, with the majority of suffixes in Serbian language, takes a 
central position. Semantic range of suffix -ice, however passes to some other formative categories and sub-categories. Suffix -ica enters into the circle of the most productive formative means for marking subjects in Serbian language (Stevanović, 1975: 524), wherein the paronyms are „made of nouns, adjectives, numbers, verbs and adverbs, and it is involved in prefix-suffix formation and complex-suffix formation" (Babih, 1986: 135). From that fact follows its broad representation in all formative categories for marking subjects, and because of that, not only in Serbian but also in other Slavic language, there are a great number of discussions and articles on the origin, structure and its procedures.

Our material shows that suffix -ica has a widespread means of formation which serves for shaping formative-semantic category: nomina agentis. Within this formative-semantic categories nouns are formed out of verb stem, on one formative model and from the stem of passive verbal adjective.

By all mentioned paronyms the function of motivating word, as we have already said, plays passive verbal adjective, which using these paronyms, primarily, provides the meaning of the doer of the action. The truth is, in some cases paronym gets different semantic nuances which can be contextually defined. So, paronyms varalica (crook), izmišljalica (a person who emballishes), lunjalica (a person who wanders), namisljalica, odalica, except of it basic meaning of a doer of the action, have also nuance of decorativeness. Some other paronyms show certain semantical specifities, as, for example, izbjeglica (a refugee), prebjeglica (a person who escaped to another country), pridošlica (a person who came and stayed), which have experiences certain semantic modification in meaning change of the doer due to the change of its own shape by some act in the past (Matijašević, 1986)

\section{SUFFIX -KA}

Suffix -ka is the oldest Slavic motion suffix. It is very productive in the service of feminine nouns in some formative categories. This character is of general Slavic origin. With this function, this suffix, except in Slovenian language as said by R. Bokovic (Bošković, 1936), appears in all Slavic languages. Somewhat in this service, in Serbian language, it is replaced by suffix -ica. Still, it is used in Serbian language for derivation of feminine nouns as the names for professions and actions doers. With the suffix -ka, nouns are formed „out of nouns, verbs, numbers and adverbs by prefix-suffix formation or different kinds of complex-suffix formation“" (Babih, 1986: 238).

About suffix -ka, which is, about its origin, functions, meaning, prevalence, many formation scientists have talked about. Surely, special place among them belongs to Boskovic, who in the essay „The development of suffixes in South-Slavic linguistic community“, discusses on suffix -ka from both synchronous and diachronic aspects. Following Boskovic, similar views about suffix -ka, as well as about other suffixes, supported many other word formation 
scientist, both, native and foreign (Matijašević, 1970; Терзић, 1990:16; Вендина \& Толстой, 1990: 1-201, Земская, 1973: 1-304). As the word formation constituted itself into a separate scientific discipline, suffixes and their opposite meaning attracted more attention. By confrontation, word formation scientists came to important cognitions, not only form word formation but also from lexicography, lexicology, morphology, semantics and other disciples.

In the majority of Slavic languages suffix -ka is classified in the order of frequent central suffixes. Confrontation way of research in related languages „does not exclude intervention of diachronic factor in order for better consideration of systematic and functional relations among those languages" (Терзић, 1990: 16).

\section{RESEARCH OF RELATED LANGUAGES}

At the confrotative way of research of related languages, the researchers do not dwell only on the statements about differences and similarities, but they explain them, often from diachronic and synchronous aspects. Here, we will deal only with some of them. In the study „Наставки со експресионо значење кај именките“ (Markov, 1981: 247-254), it is stated that suffix -ka takes central place in Macedonian language. Author stresses that, besides more meanings and functions suffix -ka has the basic diminutive and hypocoristic meaning. Within the study „The differentiation of Slavic languages on the basis of word formation" by Vendina, who carries out some interesting observations. Speaking about the central suffixes in Slavic languages, she discusses about three formative categories: „mutation“, „modification“ and „transposition“ (Вендина \& Толстой, 1990: 27). However, when it comes to suffix -ka, she especially stresses out that the basic meanings are, in all Slavic languages, except of Serbian languages, diminutive and feminine meaning (Вендина, 1989: 46). Extensive study by Stjepan Babic should be noted here. In its study, suffix -ka is being discussed from different aspects. However, his fundamental attention is drawn to the relation between the motivating word and suffix -ka (Babić, 1986: 238-248).

Among Serbian researchers on suffix -ka, word formation scientists and authors of normative grammars wrote about suffix -ka. Both agree on that suffix $\mathrm{ka}$ is one of the most productive ones in Serbian language. Jelka Matijasevic (Matijašević, 1970: 563), studying this suffix from confrotative point of view, states that he, compared to Russian one, in Serbian language, expressed pejorative and augmentative meaning, besides diminutive meaning. Within the frames of Serbian language, from lexical-semantic plan, detail description of meaning structure and suffix -ka function has been given by Olga Ristic (Ristić, 1970). Studying motion suffixes in Serbian languages, word formation scientist state that suffix -ka is not only frequently but also semantically diverse derivation mean. 


\section{CONCLUSION}

In this paper, it is concluded that the foundation or word formation gave Aleksandar Belic. On these findings lead us scientific papers both in Slavic literature, and so from our Serbian. So, no matter from which science center came, researchers look back on theoretical discussions and work of Professor Aleksandar Belic. In this paper we present a chronological series of Russian, Czech, Bulgarian, and Serbian foundation or word that their views and research based on the model of the founders professor Aleksandar Belic.

\section{REFERENCES}

Babić, S. (1986). Tvorba riječi u hrvatskom književnom jeziku - nacrt za gramatiku. Zagreb: Jugoslavenska akademija znanosti i umjetnosti : Globus.

Belić, A. (1901). Zur Entwicklungsgeschichte der slavischen Deminutivund Amplificativsuffixe. Leipzig: Breitkopf \& Härtel.

Belić, A. (1949). Savremeni srpskohrvatski književni jezik. Deo 2, nauka o građenju reči. Beograd: Naučna knjiga.

Belić, A. (1951). Oko našeg književnog jezika - članci, ogledi i popularna predavanja. Beograd: Srpska književna zadruga.

Bošković, R. (1936). Razvitak sufiksa u južnoslovenskoj jezičkoj zajednici. Beograd: Državna štamparija Kraljevine Jugoslavije.

Вендина, Т.И., \& Толстой, Н.И. (1990). Дифференщиаџия славянских языков по даннылм словообразования. Москва: Наука.

Вендина, Т.И. (1989). Опыт разработки модели сопоставительного описания словообразовательных систем русского и сербскохорватского языков. Зборник Матице српске за филологију и лингвистику, 32(2), 99-107.

Дмитренко, С.Н. (1970). Грамматика современного русского литературного языка. Москва: Наука.

Dokulil, M. (1962). Tvoření slov v češtině 1: Teorie odvozování slov. Praha: Nakladatelství Československé akademie věd.

Земская, Е.А. (1973). Современный русский язык и словообразование. Москва: Просвещение.

Зенков, Г.С. (1969). О некоторых задачах учения о словообразовании. Вопросы филологии, 70-79.

Ivić, M. (1960). Obeležavanje imeničkog roda u srpskohrvatskom književnom jeziku. Naš jezik, 10(7), 194-211.

Maretić, T. (1963). Gramatika hrvatskoga ili srpskoga književnog jezika . Zagreb: Matica Hrvatska.

Maretić, T. (1931). Gramatika i stilistika hrvatskoga ili srpskoga književnog jezika. Zagreb: Obnova. 
Markov, B. (1981). Imenice sa značenjem lica ženskog pola u srpskohrvatskom jeziku. In: Naučni sastanak slavista u Vukove dane. 177-187.

Matijašević, J. (1970). Sufiks -ka u ruskom jeziku i njegovi ekvivalenti u srpskohrvatskom. In: Zbornik Filozofskog fakulteta u Prištini. Priština: Filozofski fakultet.525-564.

Matijašević, J. (1970). Neki ruski tvorbeni tipovi i njihovi srpskohrvatski ekvivalenti. Živi jezici, 12/13, 15-23.

Matijašević, J. (1986). Iz problematike imenica tipa nomina agentis. Južnoslovenski filolog, 42, 115-128.

Молочко, Г.А. (1984). Современный русский язык : словообразование. Минск: Вышэйшая школа.

Ristić, O. (1970). Leksičko - semantičke odlike tvorbe imenica u nekih srpskih i hrvatskih romantičarskih pesnika. Južnoslovenski filolog, 28(1-2), 219320.

Nikolić, S. (1967). Nomina agentis u staroslovenskom jeziku. Južnoslovenski filolog, 27(1-2), 1-84.

Stevanović, M. (1975). Savremeni srpskohrvatski jezik. Beograd: Naučna knjiga.

Терзић, Б. (1990). Названия лиц с суффиксами -ец//-ац в русском и сербохорватском языках. Zbornik Matice srpske za slavistiku, 39, 113-123.

Тешановић, Д. (2003). Творбене категорије и поткатегорије у језику Бранка Ћопића. Бања Лука: Филозофски факултет.

Симеон, Р. (1969). Енциклопедијски рјечник лингвистичких назива. Загреб: Матица хрватска..

Stanojčić, Ž. (1996). Morfologija, sintaksa i frazeologija. U: M. Radovanović (Ur.), Srpski jezik na kraju veka. Beograd: Institut za srpski jezik SANU; Beograd: Službeni glasnik.111-141.

\title{
РЕЦЕПЦИЈА БЕЛИЋЕВОГ УЧЕЊА О ТВОРБИ РИЈЕЧИ У СЛОВЕНСКИМ ЈЕЗИЦИМА
}

\author{
Драго В. Тешановић ${ }^{1}$
}

Сажетак: Овај рад на свјетлост дана доноси релевантне чињенице из творбе ријечи, која је у прошлости била једна од централних научних дисциплина у српском језику. То првенствено показују Белићеви радови који су у словенском свијету прихваћени као темељ за ову научну

\footnotetext{
${ }^{1}$ drago_tesanovic@yahoo.com, Унивезитет у Бањој Луци, Филолошки факултет
} 
90

дисциплину. Дакле, угледни русисти крајем двадесетог вијека враћају се на теоријске погледе А. Белића, у дериватологији, те тако творбу ријечи његовог времена убрајају као централну научну дисциплину. По угледу на Белићеве теоријске осврте у дериватологији настали су многи радови еминентних стручњака у русистици, чешком и бугарском језику.

Кључне ријечи: дериватологија, грађење речи, творба речи, рецепција, језик. 


\title{
РЕЦЕПЦИЈА БЕЛИЋЕВОГ УЧЕЬА О ТВОРБИ РИЈЕЧИ У СЛОВЕНСКИМ ЈЕЗИЦИМА
}

\author{
Драго В. Тешановић ${ }^{l}$
}

Сажетак: Овај рад на свјетлост дана доноси релевантне чињенице из творбе ријечи, која је у прошлости била једна од централних научних дисциплина у српском језику. То првенствено показују Белићеви радови који су у словенском свијету прихваћени као темељ за ову научну дисциплину. Дакле, угледни русисти крајем двадесетог вијека враћају се на теоријске погледе А. Белића, у дериватологији, те тако творбу ријечи његовог времена убрајају као централну научну дисциплину. По угледу на Белићеве теоријске осврте у дериватологији настали су многи радови еминентних стручњака у русистици, чешком и бугарском језику.

Кључне ријечи: дериватологија, грађење речи, творба речи, рецепција, језик.

\section{УВОД}

Дериватолошка истраживања у српском језику имају давнашње успјешне почетке, али и релативно скромне опште домете, посебно ако се упореде са одговарајућим приликама у неким другим словенским језицима. То показују и опсежна поглавља о творби ријечи у старим граматичким приручницима нашега језика (Maretić, 1931: 252-358; 1963: 299 420; Белић, 1949: 1-329) као и у новијима (Стевановић, 1975: 387-591; Бабић, 1986: 1550), али и прилично оскудан списак ширих, општих или специјализованих, истраживања (Ристић, 1970: 387-451; Николић, 1967: 1-84); иако се у последњих 20-30 година појавило мноштво мањих прилога о најразличитијим проблемима творбе ријечи у српско (хрватско)м језику (Бабић, Матијашевић, Терзић, Анчић - Обрадовић, Барић и др.) и са различитих аспеката (најчешће дескриптивног, врло успјешно

\footnotetext{
${ }^{1}$ drago_tesanovic@yahoo.com, Унивезитет у Бањој Луци, Филолошки факултет
} 
конфронтативног, а понекад само теоријског). Овај рад ће донијети неке битне чињенице из творбе ријечи у српском језику на основу модела професора Александра Белића.

\section{ЗНАЧАЈ БЕЛИЋЕВИХ РАДОВА ЗА ТВОРБУ РИЈЕЧИ У СРПСКОМ ЈЕЗИКУ, КАО И У СЛАВИСТИЦИ}

О дериватолошким радовима констатовали смо у претходним реченицама, међутим, у овоме чланку желимо да прикажемо значај научног стваралаштва Александра Белића, у окриљу ове научне дисциплине. Ипак, прије него што пређемо на ову научну дисциплину, неопходно је казати како проф. Белић дефинише језик. Вјероватно нам је позната свима његова општа дефиниција кад каже да: „Језик служи као средство за споразумијевање". Међутим, при отварању Филозофског факултета у Новом Саду изрекао је: „Ја ћу говорити о значају оне науке чији је предмет најближи сваком човеку, а то је наука о сталном пратиоцу свих наших мисли и осећања, о сталном изразу њихову, његовој снази и лепоти - о нашем језику". Писати о Белићевим радовима и представљати их у научној области која је на неки начин поодавно и запостављена, а чини нам се баш у оно вријеме када је била на пиједасталу у словенским језицима и то оним чија наука представља срж славистике. Српски лингвисти, без обзира гдје се налазе и које задатке обављају проф. Александру Белићу дају значајно мјесто у окриљу дијахроних дисциплина, што је у потпуности и тачно. Међутим, ако детаљно прегледамо Белићеве радове, из области творбе речи (савременог српског језика) није тешко закључити да су његови радови незаобилазни, а посебно с теоријског аспекта. Проф. Белић, својим радовима ударио је темеље словенској дериватологији што показују у својим релевантним дјелима истакнути слависти на руском, чешком и бугарском језику. Дакле русисти на пијадестал стављају Белићеву расправу, као велики домет српске дериватологије о поријеклу и у потреби деминутивних и аугментативних суфикса у словенским језицима (Белић, 1901: 134-206). Белићево истраживање, наиме, налази се у основи модерне дериватолошке словенске науке, прије свега „лингвистичке разраде проблема диференцијације словенског језичког свијета по подацима творбе ријечи" (Вендина \& Толстой, 1990:6), али и по другим значајним теоријским доприносима. Неки од таквих суфикса, наиме, функционално се сматрају јужнословенскима, мада је и та група језика по многим творбеним појединостима изразитије диференцирана (нпр., суфикс -ниц(а) у локационом значењу, -иц(а) у моционом, суфикси с елементима -ц, и -ч у деминутивном значењу (Вендина \& Толстой, 1990:6). На сличној линији налази се и позната расправа Лекова (1958), а посљедњих тридесетак година дериватолошка истраживања у словенском свијету доживјела су изузетно снажан размах, посебно послије опсежних расправа о творби ријечи у чешком и руском језику (Dokulil, 1962; Дмитренко, 1970), али и у неким 
другим словенским језицима. Све појединости о којима говоримо утицале су на то да се дериватологија током посљедњих деценија све изразитије почиње конституисати као засебна област лингвистичких истраживања, што је досад било ограничено и, отуда, знатно отежано њеном повезаношћу и испреплетеношћу са другим већ осамостаљеним дисциплинама - какве су морфологија (са морфофонологијом), лексикологија и синтакса. Што се, међутим, тиче прилика у српском језику, мора се имати у виду традиционална запостављеност дериватолошких истраживања у односу на друге области језика, као и одсуство систематског и континуираног рада у овој области. Уз овакву тврдњу можемо се увјерити ако, рецимо, прегледамо Енциклопедијски рјечник лингвистичких назива, у чијем су Уводу назначене струке области из којих су обрађени термини: међу њима налазимо „фонетику, морфологију, синтаксу, лексикологију, лексикографију, дијалектологију” (Симеон, 1969: 13-34), а термин „дериватологија” се и не помиње (мада се у рјечнику, разумије се, налази много одредница из тога терминолошког система).

Године 1996. свјетлост дана угледала је научно дјело под насловом Српски језик на крају века под покровитељством Института за српски језик САНУ. У наведеном дјелу проф. Живојин Станојчић говори да Творбени модели српског књижевног језика, овог, посматраног, периода показују стабилност високог степена. У неким од класа речи, на пример у класи именица, иновација је, у ствари, више ствар узуса, употребе појединих јединица лексичког инвентара, а не ствар могућног новог модела који би се тек сада појављивао у књижевном језику (Stanojčić, 1996: 123).

\section{СУФИКС КАО ЈЕЗИЧКО СРЕДСТВО}

Имају ли се на уму све те околности, треба ипак, рећи да су главни правци дериватолошких истраживања јасно назначени и многи полазни ставови сматрају се пречишћенима, а међу њима истакли бисмо оне који се тичу саме природе суфикса као језичког средства.

Суфикс је језичка јединица која се може посматрати у оквиру тријаде: форма - значење - функција. Као значење суфикса, притом, схвата се она компонента изведене ријечи која се изражава уз помоћ суфикса (жена и жен -иц-а). Када је, међутим, ријеч о функцији суфикса, треба рећи да она може бити врло разнородна, али се из ње могу извојити двије најопштије: а) структурална - која се своди на граматичку, или морфолошку и деривациону функцију (при чему се у првом случају суфикс показује као индикатор припадности изведенице одређеној врсти ријечи, док се у другом случају он појављује као елеменат којим се формира нова језичка јединица) и б) семантичка - која може бити „објектизирана” (тј. „реално семантичка”) и „субјективна” (тј. „експресивна”). Када је ријеч о првој функцији, треба рећи да се она своди на то да се суфиксом маркира значење 
по неком обиљежју шире или уже одређеном („лице” - „лице по професионалној припадности"), док се експресивна функција своди на изражавање става говорног лица према објекту номинације (цур-а - цур ет-ак - цур - ет - ин-а).

Мање је, међутим, сагласности међу дериватолозима о главним карактеристикама творбеног система једнога језика као цјелине. Ми ћемо овдје покушати да представимо модел творбене анализе који смо покушали примијенити у овом раду.

Полазећи од тога да се у разматрању творбеног система једнога језика, по различитој хијерархији, могу примијенити различити класификациони критерији, ми смо се опредијелили за рјешавање по коме ћемо творбено-семантичко макропоље посматрати као творбену категорију, а одговарајућа микропоља као творбене поткатегорије. За такав поступак оправдање налазимо у чињеници да се наше истраживање не односи на цјелину творбенога система него само на онај његов сегмент који се тиче означавања лица у прозном дјелу Бранка Ћопића (Тешановић, 2003:11).

Творбена категорија се, иначе, може дефинисати и као „укупност изведеница које се у оквирима творбеног разреда издвајају према лексичкограматичким својствима мотиватора”, а које се могу изводити „од именица, придјева, бројева, замјеница, глагола, прилога итд.”, (Молочко, 1984: 146147). Творбену категорију слично дефинишу и неки други аутори: од творбеног типа а она се разликује тиме што није везана јединством форманта (Dokulil, 1962: 203-204).

Поред наведене класификације, у литератури налазимо и другачије класификационе поступке у анализи творбеног система језика. Тако, на примјер, Докулил као прво, „основно диференцијално обиљежје при формирању творбеног система истиче начин творбе изведених ријечи, а лексичко-граматички карактер изведеница, њихову припадност одређеној врсти ријечи ставља на друго мјесто" (Dokulil, 1962: 218). Затим, Зенков у основу организовања творбеног система језика, тј. у основу организовања творбеног система језика, тј. у основу класификације изведених ријечи, ставља ,јединство лексичко-граматичког обиљежја мотивирајућих ријечи у споју, јединству с творбеним начином, средством, поступком" (Зенков, 1969: 76). С обзиром на то да неке изведене ријечи могу непосредно да се мотивишу разним мотиваторима, тј. мотивирајућим ријечима које се односе на разне врсте ријечи, а такође и то да многе изведенице могу имати разна творбена значења, у низу случајева једна иста ријеч (у потпуности или у засебним лексичко-семантичким варијантама) може да се односи на разне пододјељке творбеног система језика (на разне творбене разреде, категорије, низове, групе). На основу изнесених констатација, а у складу са циљем овога рада, нас ће интересовати оне творбене категорије које се у српском језику остварују творбеним средствима. Творбена средства су основа, префикси и суфикси. 
Структура творбене категорије у принципу је увијек двочлана. Појава која треба да буде номинована увијек на почетку укључује у одређену појмовну класу, која у датом језику има свој категоријални израз, а затим се у оквирима те класе она одређује неким обиљежјем. Класа улази у творбену структуру појма као оно што се одређује (творбена основа), а формант као онај елеменат којим се база одређује. Творбена основа увијек је проста, док формант може бити прост или сложен. У српској дериватолошкој литератури налазимо термине „творбена основа” и „творбени формант”, што у руском језику одговара терминима „мотивирајућа основа” и „творбени формант”. Творбени формант је, како у формалном тако и у семантичком погледу, најмањи творбени елемент међу осталим елементима по којима се нека ријеч разликује од ријечи које су у мотивационој вези с њим.

\section{СРПСКА ТВОРБА РИЈЕЧИ - МОДЕЛ АЛЕКСАНДРА БЕЛИЋА}

Послије истакнутих релевантних научних чињеница о проф. Белићу, које су о њему говорили његови наследници, а посебно страни дериватолози, који тврде да творба ријечи почива на његовим теоријским основама, свакоме ко то прочита, част је, а и задовољство да спозна да је у савременој словенској дериватологији уткана српска творба ријечи односно модел Александра Белића.

Још је Белић, наиме, дефинисао књижевни језик као такав „по томе што се њиме обрађују књижевни предмети, што је он представник културног мишљења", упућујући притом на потребу да се и историја тога књижевног језика проучава-описом језика „од писца до писца, од књижевне врсте до књижевне врсте” (Belić, 1951: 6-79).

У суштни, исти је став пост-белићевске модерне лингвистике. Њени најистакнутији представници, када утврђују потребу писања дескриптивне граматике савременог српскога књижевнога језика, изричити су у захтеву да „само језик модерних писаца треба да оправда данашње граматичке норме” (Ivić, 1960).

Наведене констатације српских као и страних дериватолога, навеле су нас да се прихватимо анализе прозних остварења у језику Бранка Ћопића, с аспеката творбе ријечи. Анализу у језику Бранка Ћопића извршили смо у окриљу творбених категорија nomina agentis и nomina attributiva, гдје смо дошли до изванредних резултата који су специфични по много чему. Познато је да су у српском језику односно у нормативним граматикама српског језика централни суфикси су -ица и -ка. У прозним остварењима Бранка Ћопића централни суфиксу су такође -ица и -ка у окриљу творбених категорија, као и њихових поткатегорија. Наша анализа је показала да суфикси за обиљежавање лица доминирају у језику истакнутог српског писца Бранка Ћопића. У овоме раду желимо да скренемо пажњу свим онима 
који желе да истражују језик писаца с аспекта дериватологије да пред собом имају кључну српску творбу, као нпр. Белићеве, Бошковићев, Стевановићеве радове, као и других српских дериватолога.

Термином nomina agentis зову се имена лица која у мотивирајућој ријечи имају агенс. Облик мотивирајуће ријечи, притом, једнак је глаголској основи којом се означава некадашња којом се изводе, прије свега, имена називи вршиоца радње у потпуном смислу ријечи. Ова творбена категорија код већине суфикса у српском језику заузима централно мјесто. Семантички опсег суфикса -ица, међутим, прелази и на неке друге творбене категорије и поткатегорије. Суфикс -ица улази у круг најпродуктивнијих творбених средстава за обиљежавање лица у српском језику (Stevanović, 1975: 524), при чему се њиме изведенице „творе од именица, придјева, бројева, глагола и прилога, а судјелује и у префиксално-суфиксалној и сложено-суфиксалној творби" (Babić, 1986:135). Из те чињенице произилази и његова широка заступљеност у свим творбеним категоријама за означавање лица, а због тога, не само у српском него и у другим словенским језицима, постоји велики број расправа и чланака о поријеклу, структури и његовим функцијама.

Наш материјал показује да је суфикс -ица веома распрострањено средство деривације које служи за уобличавање творбено - семантичке категорије: nomina agentis. У оквиру ове творбено-семантичке категорије изводе се именице од глаголске основе по једном творбеном моделу и то од основе радног глаголског придјева.

Код свих наведених изведеница у функцији мотивирајуће ријечи је, као што смо рекли, радни глаголски придјев, који овим изведеним ријечима, прије свега, обезбјеђује значење вршиоца радње. Истина, у појединим случајевима изведеница добија и друге семантичке нијансе које могу бити контекстуално одређене. Тако изведене ријчи варалица, измишљалица, луњалица, намишљалица, одалица, поред основног значења вршиоца радње, имају и нијансу пејоративности. Још неке изведенице показују одређене семантичке специфичности, као, на примјер, избјеглица, пребјеглица и придошлица, које су доживјеле и извјесну семантичку модификацију у смјеру промјене значења агенса усљед измјене свога сопственог стања неким чином у прошлости (Matijašević, 1986).

\section{СУФИКС -КА}

Суфикс -ка најстарији је словенски моциони суфикс. Он је врло продуктиван у служби именица женскога рода код неких творбених категорија. Овај његов моциони карактер је општесловенског поријекла. Са моционом функцијом овај суфикс, осим у словеначком, како каже Р. Бошковић_(Bošković, 1936), јавља се у свим словенским језицима. Донекле и у овој служби, у српском језику, њега замјењује суфикс -ица. Ипак, он се 
користи у српском језику за извођење именица женског рода као назива ималаца занимања и вршиоца радње. Суфиксом -ка граде се именице „од именица, глагола, бројева и прилога суфиксалном, префиксално суфиксалном и разним типовима сложено - суфиксалне творбе" (Babić, 1986: 238).

О суфиксу -ка, односно о његовом поријеклу, функцијама, значењу и распрострањености и сл. говорили су многи дериватолози. Свакако да посебно мејсто међу њима заузима Р. Бошковић, који у студији „Развитак суфикса у јужнословенској језичној заједници" расправља о суфиксу -ка и са синхронијског и са дијахронијског аспекта. По угледу на Р. Бошковића о суфиксу -ка, као и о другим суфиксима, сличне погледе заступали су и многи други дериватолози, како страни тако и домаћи (Matijašević, 1970; Terzić, 1990:16; Вендина \& Толстой, 1990: 1-201, Земская, 1973: 1-304). Како се творба ријечи с временом конституисала у засебну научну дисциплину, већу пажњу привлачили су суфикси и њихово конфронтативно проучавање. Конфронтирањем су дериватолози долазили до важних сазнања, не само из творбе ријечи него и из лексикографије, лексикологије, морфонологије, семантике и других научних дисциплина.

У већини словенских језика суфикс -ка дериватолози сврставају у ред фреквентних, централних суфикса. Конфронтативни начин истраживања у сродним језицима „не искључује интервенцију дијахроног фактора у циљу бољег сагледавања системских и функционалних односа међу тим језицима" (Терзић, 1990: 16).

\section{ИСТРАЖИВАЮА СРОДНИХ ЈЕЗИКА}

При конфронтативном начину истраживања сродних језика истраживачи се не задржавају само на констатацији разлика или сличности, већ их и објашњавају, често и са дијахроног и синхроног становишта. Овде ћемо се позабавити само некима од њих. У студији „Наставки со експресионо значење кај именките” (Markov, 1981: 247-254), констатује се да суфикс -ка заузима централно мјесто у македонском језику. Аутор, између осталог, истиче да, поред више значења и функција, суфикс -ка има основно деминутивно и хипокористично значење. У оквиру студије „Диференцијација словенских језика по подацима творбе ријечи” Вендина износи такође интересантна запажања. Говорећи о централним суфиксима у словенским језицима, она расправља о три творбене категорије: „мутацији”, „модификацији” и „транспозицији” (Вендина \& Толстой, 1990: 27). Међутим, у вези са суфиксом -ка она посебно наглашава да су основна његова значења у свим словенским језицима, осим у српском језику, деминутивна и феминативно значење (Вендина, 1989: 46). Овдје би требало поменути опсежну студију Стјепана Бабића у којој се са више аспеката 
расправља о суфиксу -ка. Међутим, његова основна пажња усредсређена је на однос мотивирајуће ријечи и суфикса -ка (Babić, 1986: 238-248).

Међу српским истраживачима о суфиксу -ка писали су како дериватолози тако и аутори нормативних граматика. И једни и други слажу се у томе да је суфикс -ка један од продуктивнијих суфикса у српском језику. Тако Јелка Матијашевић (Matijašević, 1970: 563), проучавајући овај суфикс са конфронтативне тачке гледишта, констатује да он, за разлику од руског, у српском језику, поред деминутивног, изражавао пејоративно и аугментативно значење. У оквиру српског језика, са лексичко-семантичког плана, детаљан опис структуре значења и функција суфикса -ка дала је Олга Ристић (Ristić, 1970). Проучавајући моционе суфиксе у српском језику, дериватолози констатују да суфикс -ка није само фреквентно него и семантички разноврсно деривационо средство.

\section{ЗАКЉУЧНА РАЗМАТРАҢА}

У овоме раду, неопходно је констатовати, да је темеље дериватологији, односно творби ријечи подарио Александар Белић. На такве закључке наводе нас научни радови како из славистичке литературе, а тако и из наше српске. Дакле, без обзира из кога научног центра долазили, дериватолози се осврћу на теоријске расправе и радове професора Александра Белића. У овоме раду представили смо хронолошким низом руске, чешке, бугарске, а и српске дериватологе који своје погледе и истраживања заснивају по угледу на утемељивача дериватологије професора Александра Белића.

\section{ЛИТЕРАТУРА}

Babić, S. (1986). Tvorba riječi u hrvatskom književnom jeziku - nacrt za gramatiku. Zagreb: Jugoslavenska akademija znanosti i umjetnosti : Globus.

Belić, A. (1901). Zur Entwicklungsgeschichte der slavischen Deminutivund Amplificativsuffixe. Leipzig: Breitkopf \& Härtel.

Belić, A. (1949). Savremeni srpskohrvatski književni jezik. Deo 2, nauka o građenju reči. Beograd: Naučna knjiga.

Belić, A. (1951). Oko našeg književnog jezika - članci, ogledi i popularna predavanja. Beograd: Srpska književna zadruga.

Bošković, R. (1936). Razvitak sufiksa u južnoslovenskoj jezičkoj zajednici. Beograd: Državna štamparija Kraljevine Jugoslavije.

Вендина, Т.И., \& Толстой, Н.И. (1990). Дифференцииция славянских языков по данным словообразования. Москва: Наука. 
Вендина, Т.И. (1989). Опыт разработки модели сопоставительного описания словообразовательных систем русского и сербскохорватского языков. Зборник Матице српске за филологију и лингвистику, 32(2), 99-107.

Дмитренко, С.Н. (1970). Грамматика современного русского литературного языка. Москва: Наука.

Dokulil, M. (1962). Tvoření slov v češtině 1: Teorie odvozování slov. Praha: Nakladatelství Československé akademie věd.

Земская, Е.А. (1973). Современный русский язык и словообразование. Москва: Просвещение.

Зенков, Г.С. (1969). О некоторых задачах учения о словообразовании. Вопросы филологии, 70-79.

Ivić, M. (1960). Obeležavanje imeničkog roda u srpskohrvatskom književnom jeziku. Naš jezik, 10(7), 194-211.

Maretić, T. (1963). Gramatika hrvatskoga ili srpskoga književnog jezika . Zagreb: Matica Hrvatska.

Maretić, T. (1931). Gramatika $i$ stilistika hrvatskoga ili srpskoga književnog jezika. Zagreb: Obnova.

Markov, B. (1981). Imenice sa značenjem lica ženskog pola u srpskohrvatskom jeziku. In: Naučni sastanak slavista u Vukove dane. 177-187.

Matijašević, J. (1970). Sufiks -ka u ruskom jeziku i njegovi ekvivalenti u srpskohrvatskom. In: Zbornik Filozofskog fakulteta u Prištini. Priština: Filozofski fakultet.525-564.

Matijašević, J. (1970). Neki ruski tvorbeni tipovi i njihovi srpskohrvatski ekvivalenti. Živi jezici, 12/13, 15-23.

Matijašević, J. (1986). Iz problematike imenica tipa nomina agentis. Južnoslovenski filolog, 42, 115-128.

Молочко, Г.А. (1984). Современный русский язык : словообразование. Минск: Вышэйшая школа.

Ristić, O. (1970). Leksičko - semantičke odlike tvorbe imenica u nekih srpskih i hrvatskih romantičarskih pesnika. Južnoslovenski filolog, 28(1-2), 219320.

Nikolić, S. (1967). Nomina agentis u staroslovenskom jeziku. Južnoslovenski filolog, 27(1-2), 1-84.

Stevanović, M. (1975). Savremeni srpskohrvatski jezik. Beograd: Naučna knjiga.

Терзић, Б. (1990). Названия лиц с суффиксами -ец//-ац в русском и сербохорватском языках. Zbornik Matice srpske za slavistiku, 39, 113-123.

Тешановић, Д. (2003). Творбене категорије и поткатегорије у језику Бранка Ћопића. Бања Лука: Филозофски факултет. 
Симеон, Р. (1969). Енциклопедијски рјечник лингвистичких назива. Загреб: Матица хрватска..

Stanojčić, Ž. (1996). Morfologija, sintaksa i frazeologija. U: M. Radovanović (Ur.), Srpski jezik na kraju veka. Beograd: Institut za srpski jezik SANU; Beograd: Službeni glasnik.111-141.

\title{
RECEPTION OF BELIC'S LEARNING ON WORD FORMATION IN SLAVIC LANGUAGES
}

\author{
Drago V. Tesanovic ${ }^{1}$
}

Abstract: This paper brings into daylight some relevant facts from word formation, which was one of the central disciplines in Serbian language in the past. This, primarily, show Belic's works which, in Slavic world, are accepted as the foundation for this discipline. Therefore, prominent Russian from the end of twentieth century return to the theoretical perspectives of A. Belic, in derivatology, so word formation of his time count as the central discipline. Modeled on Belic's theoretical reviews in derivation, many works by eminent experts in Russian, Czech, and Bulgarian language have appeared.

Key words: derivatology, building words, word-formation, reception, language.

Примљен: 05.06.2017.

Прихваћен: 13.12.2017.

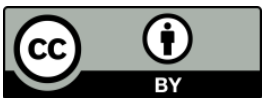

${ }^{1}$ drago_tesanovic@yahoo.com, University of Banja Luka, Faculty of Philology 